OPEN ACCESS

Edited by:

Jude Ezeh Uzonna,

University of Manitoba, Canada

Reviewed by:

Rajiv Kumar,

Banaras Hindu University, India Giampietro Corradin,

Université de Lausanne, Switzerland

*Correspondence: Lynette Isabella Ochola-Oyier liochola@kemri-wellcome.org

Specialty section This article was submitted to Microbial Immunology, a section of the journal

Frontiers in Immunology

Received: 13 June 2019 Accepted: 25 September 2019 Published: 15 October 2019

Citation:

Kimenyi KM, Wamae K and Ochola-Oyier LI (2019) Understanding P. falciparum Asymptomatic Infections: A Proposition for a Transcriptomic Approach. Front. Immunol. 10:2398. doi: 10.3389/fimmu.2019.02398

\section{Understanding $P$. falciparum Asymptomatic Infections: A Proposition for a Transcriptomic Approach}

\author{
Kelvin M. Kimenyi ${ }^{1,2}$, Kevin Wamae ${ }^{1}$ and Lynette Isabella Ochola-Oyier ${ }^{1,3 *}$ \\ ${ }^{1}$ KEMRI-Wellcome Trust Research Programme, CGMRC, Kilifi, Kenya, ${ }^{2}$ Centre for Biotechnology and Bioinformatics, \\ University of Nairobi, Nairobi, Kenya, ${ }^{3}$ Pwani University Bioscience Research Centre, Pwani University, Kilifi, Kenya
}

Malaria is still a significant public health burden in the tropics. Infection with malaria causing parasites results in a wide range of clinical disease presentations, from severe to uncomplicated or mild, and in the poorly understood asymptomatic infections. The complexity of asymptomatic infections is due to the intricate interplay between factors derived from the human host, parasite, and environment. Asymptomatic infections often go undetected and provide a silent natural reservoir that sustains malaria transmission. This creates a major obstacle for malaria control and elimination efforts. Numerous studies have tried to characterize asymptomatic infections, unanimously revealing that host immunity is the underlying factor in the maintenance of these infections and in the risk of developing febrile malaria infections. An in-depth understanding of how host immunity and parasite factors interact to cause malaria disease tolerance is thus required. This review primarily focuses on understanding anti-inflammatory and pro-inflammatory responses to asymptomatic infections in malaria endemic areas, to present the view that it is potentially the shift in host immunity toward an anti-inflammatory profile that maintains asymptomatic infections after multiple exposures to malaria. Conversely, symptomatic infections are skewed toward a pro-inflammatory immune profile. Moreover, we propose that these infections can be better interrogated using next generation sequencing technologies, in particular RNA sequencing (RNA-seq), to investigate the immune system using the transcriptome sampled during a clearly defined asymptomatic infection.

Keywords: asymptomatic infection, malaria, immunity, cytokines, RNA-seq

\section{INTRODUCTION}

Malaria is a significant public health burden with an estimated 219 million new cases and 435,000 deaths reported in 2017 (1). Nearly half of the world's population is at risk of contracting malaria, with tropical and subtropical areas showing the highest prevalence (2). Malaria infection is caused by protozoan parasites of the genus Plasmodium that affect humans. P. falciparum is globally the most deadly and is the most prevalent parasite in Africa (3). P. falciparum malaria ranges from severe to uncomplicated or mild and to the poorly understood asymptomatic infections. Such diverse outcomes are due to the intricate interplay between factors derived from the human host, parasite, and environment (4). At the genomic level, differences in gene expression by the host during host-parasite interactions may account for the various clinical manifestations (5). 
Specifically, gene pathways that regulate cytokine signaling and complement regulation as well as the production of immunoglobulins have been implicated (6). A strong proinflammatory response has been associated with an increased risk of febrile malaria, severe malaria anemia (7) or cerebral malaria (8), while a weak response has been associated with asymptomatic infection (9). Hence, the balance between pro-inflammatory and anti-inflammatory cytokine production appears to be important in influencing the outcome of malaria infections. Identification of markers that can diagnose the clinical manifestations of $P$. falciparum infections, in addition to symptoms, is important in predicting prognosis and directing treatment strategies.

Malaria infections are mainly characterized by a recurrent cycle of fever and chills. Other symptoms include vomiting, shivering, convulsions, and anemia caused by hemolysis (10). In some cases, these symptoms are not observed, and the infection is described as asymptomatic in individuals without a recent history of antimalarial treatment (11). Once an individual is infected with the parasite, immune factors are tasked with reducing parasite numbers, i.e., anti-parasite immunity, and preventing manifestation of clinical symptoms, anti-disease immunity. In asymptomatic individuals, immunity is skewed toward antidisease rather than anti-parasite immunity. The mechanisms behind this phenomena are still unclear and more studies are required to understand how anti-disease immunity is induced and its potential for application in vaccine development (12).

\section{DEFINING ASYMPTOMATIC Plasmodium falciparum INFECTIONS}

The study of asymptomatic infections is still hampered by the lack of standard criteria for defining these infections $(4,11)$. This is due to the wide range of definitions that complicates the comparison of results across studies (Table 1). The most basic definition seems to be the presence of parasitemia and the absence of malaria symptoms, mainly fever (axillary temperature $\left.<37.5^{\circ} \mathrm{C}\right)(14,19,20)$. This definition is ambiguous and most studies have modified it by incorporating strict inclusion criteria. Laishram et al. (4) summarized the diagnostic criteria used to define asymptomatic individuals in different studies and made several recommendations. They suggested the use of longitudinal follow ups, quantifying parasitemia rather than reporting its presence or absence and the use of PCR to identify asymptomatic infections in a population (4). Since then, the criteria have improved by incorporating the latest advancement in PCR, the loop-mediated isothermal amplification (LAMP), biomarkers to detect the parasite and use of cohorts that ensure reliable information about clinical history and follow ups. This allows for the exclusion of those who experienced symptoms in the recent past and then sought treatment. However, there is no consensus on the duration of history and it ranges from 2 weeks to 1 month $(5,14,20)$. The longitudinal follow-ups after diagnosis reduces the chances of "false" asymptomatic parasitemia that are defined during $P$. falciparum incubation toward a clinical outcome. The duration of follow-up varies depending on whether the study is interested in asymptomatic parasitemia or the eventual symptomatic outcome $(5,14)$. The method for asymptomatic parasitemia diagnosis is also important. Microscopy, with a detection threshold of $\sim 50$ parasites $\mu l^{-1}$, may miss subpatent infections, while others use PCR whose sensitivity can extend to below one parasite $\mu l^{-1}(21,22)$. Studies in Kenya, Uganda and Brazil have reported a significantly high prevalence of asymptomatic parasitemia, as much as 67 times higher, using PCR when compared to microscopy $(13,23,24)$. PCR has also helped to identify individuals with low-density parasitemia in low-transmission settings that were previously missed by microscopy (25). Although the use of PCR is technical and expensive, making it unrealistic in most field studies, it is important in improving the accuracy of diagnosing asymptomatic parasitemia (26). Interestingly, LAMP has been shown to accurately detect sub-microscopic asymptomatic Plasmodium infections (27). LAMP is cheap and easy to implement in a field setting as it does not require a thermocycler machine like PCR. In addition, several biomarkers such as lactate dehydrogenase, hemozoin and, in particular, Histidine-Rich Protein 2 that is utilized in rapid diagnostic tests (RDTs), have been used to diagnose malaria $(28,29)$. Hemozoin is an important metabolite of hemoglobin digestion by the malaria parasite and is associated with pathogenesis as well as inducing immunity to malaria (30-32). A hemozoin sensing assay has recently been shown to be 20 times more sensitive than RDTs in diagnosing Plasmodium species (33). It could be applied as a point of care test and more importantly in screening populations for asymptomatic individuals with submicroscopic parasitemia (33). More efficient diagnostic techniques are needed to effectively detect asymptomatic infections in various settings to improve the quality and reliability of data used in studying asymptomatic infections. Table 1 outlines the different criteria used in transcriptomics studies to define asymptomatic $P$. falciparum infections.

\section{UNDERSTANDING THE RISK OF DEVELOPING FEBRILE INFECTIONS}

Asymptomatic infections can act as precursors to malaria illness (34). Mass drug administration (MDA) has been suggested as an effective way of treating chronic asymptomatic infections (35, 36). However, this may interfere with the immunity maintained by these infections, thus increasing the risk of developing clinical malaria in asymptomatic individuals (37). A study in Mali treated chronic asymptomatic individuals at the end of the dry season, followed them up during the subsequent rainy season and reported that treatment of asymptomatic infections is unlikely to influence the subsequent risk of developing clinical malaria (17). Similar findings were also reported in Burkina Faso (38). A risk-benefit analysis is required to determine the tradeoffs to inform the public health impact of MDA on asymptomatic infections. The possibility of developing febrile malaria among asymptomatic carriers has been shown to vary due to transmission intensity and age (Figure 1) (20,39). A study in Kenya compared the risk of developing febrile malaria among 
TABLE 1 | Examples of inclusion criteria used to define asymptomatic individuals in transcriptomic studies.

\begin{tabular}{|c|c|c|c|c|}
\hline $\begin{array}{l}\text { Country, } \\
\text { year }\end{array}$ & $\begin{array}{l}\text { Criteria for identifying asymptomatic } \\
\text { cases }\end{array}$ & $\begin{array}{l}\text { Study subjects } \\
\text { (sample size) }\end{array}$ & Follow-up protocol, duration & References \\
\hline $\begin{array}{l}\text { Cameroon, } \\
2009\end{array}$ & $\begin{array}{l}\text { Positive thick blood smear and afebrile. No } \\
\text { history of fever and antimalarial treatment } \\
\text { in the previous } 1 \text { and } 2 \text { weeks, } \\
\text { respectively, at the time of mass screening }\end{array}$ & Children < 12 years $(13)$ & No follow-up & (5) \\
\hline Mali, 2011 & $\begin{array}{l}\text { PCR-detected } P \text {. falciparum and no fever. } \\
\text { No history of antimalarial or } \\
\text { immunosuppressive medication in the last } \\
30 \text { days and helminths }\end{array}$ & Individuals > 13 (5) & $\begin{array}{l}\text { Bi-weekly and weekly surveillance } \\
\text { for Plasmodium infection and } \\
\text { malaria episode, respectively }\end{array}$ & $(14)$ \\
\hline Gabon, 2005 & $\begin{array}{l}\text { Thin and thick blood smear and no clinical } \\
\text { symptoms }\end{array}$ & $\begin{array}{l}\text { Children } 0.5-6 \text { years } \\
\text { (ND) }\end{array}$ & Follow up for 5 consecutive days & (6) \\
\hline $\begin{array}{l}\text { Uganda, } \\
\text { 2007-2008 }\end{array}$ & Blood smear and no fever & Children 4-5 years (15) & Follow up for 7 days & $(16)$ \\
\hline Mali, 2006 & Not defined & $5-13$ years $(17)$ & $\begin{array}{l}\text { Healthy baseline before the malaria } \\
\text { season, } 7 \text { or } 14 \text { days after treatment } \\
\text { of their first malaria episode of the } \\
\text { ensuing malaria season, and a } \\
\text { subset of children followed up to } \\
\text { the } 6 \text {-month dry season }\end{array}$ & $(18)$ \\
\hline
\end{tabular}

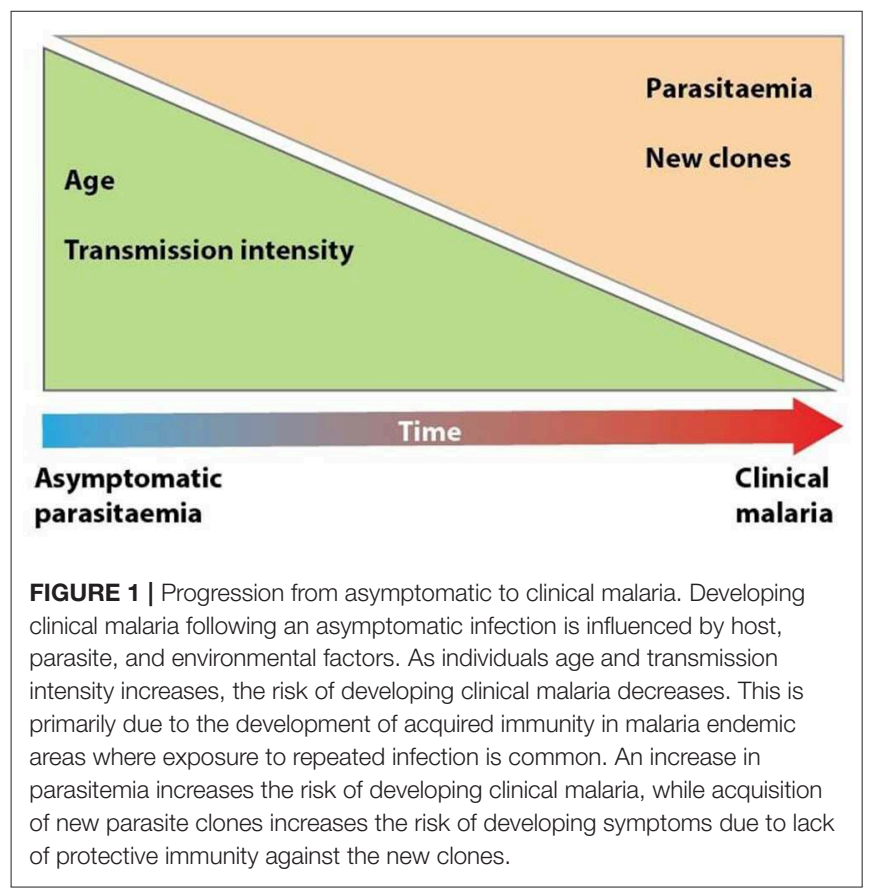

children (0-15 years) who were uninfected with $P$. falciparum and those with asymptomatic parasitemia. In lower transmission areas, asymptomatic parasitemia was linked to an increased risk of febrile malaria in children of all ages, while in moderate to high transmission areas, asymptomatic parasitemia was linked to a reduced risk of febrile malaria in children above 3 years (20). High asymptomatic parasitemia densities $(\geq 2,500$ parasites $\mu \mathrm{L}^{-1}$ ) and every 10 -fold increase in parasite density have been associated with an increased risk of developing febrile malaria, probably due to the underlying reduced host immunity $(20,39)$.
In addition, the transition from asymptomatic to symptomatic malaria may be influenced by the presence of new parasite genotypes to which an individual has not been previously exposed in the preceding asymptomatic infection, and hence they are likely to lack protective immune responses to the new genotype (40-42). P. falciparum infections in malaria endemic areas, primarily in sub-Saharan Africa, are characterized by the co-circulation of multiple $P$. falciparum clones in acute and persistent infections (43-47). This phenomenon is termed complexity of infection (COI). The presence of multiclonal infections has been associated with an increased range of antimerozoite antibody responses. Together, COI and anti-merozoite antibody responses have been associated with a reduced risk of clinical malaria (48). Carriage of certain merozoite surface protein $(m s p) 1$ genotypes have been associated with different clinical manifestations of malaria. In Nigerian children, msp1 K1 and MAD20 alleles were associated with asymptomatic malaria and a minimal risk of becoming febrile (49). Similarly, using the msp2 locus, the FC27 genotype was more prevalent in asymptomatic than in symptomatic Nigerian children (50). Other studies have shown that an increase in COI in children with asymptomatic infections is associated with an increased risk of febrile malaria in younger children, a lower risk in older children $(51,52)$ and in some cases, age had no influence $(41,53)$. Such conflicting findings on the role of COI in predicting febrile malaria could be due to methodology.

The traditional method for characterizing $P$. falciparum diversity uses nested-PCR with gel electrophoresis to detect polymorphisms in $m s p 1, m s p 2$ and glutamine rich protein (GLuRP) (54) and recently by capillary electrophoresis (55). This technique has been shown to be limited in the number of variants detected within an individual infection $(56,57)$, is insensitive to less abundant variants and is not quantitative for relative proportions of circulating variants (57). Amplicon deepsequencing overcomes these challenges as it is more sensitive 
than capillary electrophoresis in detecting minority clones and is able to quantify individual $P$. falciparum clones (58). This technique also uses less DNA since adequate amounts of amplicons are obtainable directly from dried blood spots used for screening large sample sizes (59). With increased sensitivity and number of samples that can be genotyped, deep-sequencing promises to increase our understanding of the dynamics of $P$. falciparum COI and how this relates to the outcomes of febrile malaria. An understanding of how host immunity mediates the development of febrile malaria in asymptomatic carriers is required to better understand these infections.

\section{IMMUNITY TO MALARIA}

Individuals residing in malaria endemic zones often harbor asymptomatic infections and are clinically immune due to exposure to multiple genetically complex $P$. falciparum infections over time (60). Children who have experienced repeated malaria episodes have a modified immune system $(26,61,62)$ that is for instance characterized by an increased production of immunoregulatory cytokine IL-10 and activation of neutrophils, $\mathrm{B}$ cells and $\mathrm{CD}^{+} \mathrm{T}$ cells (63). The immune system is involved in controlling disease outcome as exhibited by the fact that the parasitemia tolerated in high transmission settings is higher than that causing fever in low transmission settings (64). The chances of an infection being asymptomatic increases with age as repeated exposure to malaria leads to the development of partial antidisease immunity (65). Unfortunately, the immunity developed is not sterile, only suppressing but not eliminating the infection leading to disease tolerance and asymptomatic infection $(66,67)$. This immunity may also be lost due to a lack of continuous exposure to the parasite, resulting in elevated pro-inflammatory responses and subsequently a high risk of illness (68).

\section{IMMUNOMODULATION IN ASYMPTOMATIC MALARIA}

Modulation of immune responses has been associated with different clinical malaria manifestations $(66,69)$. The immune responses are mediated by cytokines that regulate inflammation and are thus involved in protective immunity. These cytokines include interferon gamma (IFN- $\gamma$ ), tumor necrosis factor alpha (TNF- $\alpha)$ and IL-12 $(70,71)$. Overstimulation of the immune system leading to excessive production of these cytokines and activation of immune cells is detrimental to the host as they are likely to cause severe malaria symptoms through unknown mechanisms (72, 73). However, anti-inflammatory cytokines including IL-10, IL-27 and tissue growth factor beta (TGF- $\beta$ ) were shown to be involved in dampening proinflammatory cytokines, thereby minimizing disease severity (71, 74). The presence of anti-inflammatory cytokines, especially IL10, suppresses parasite clearance, hindering the development of anti-parasite immunity, and clinical malaria (69), while promoting the development of asymptomatic infections (18). Elevated levels of IL-10 has also been linked to asymptomatic infections in pregnant women (75).
The production of anti-inflammatory cytokines has been shown to increase with repeated exposure to malaria, resulting in asymptomatic infection (18). Conversely, a lack of continuous exposure in historically exposed individuals can lead to the loss of anti-disease immunity $(68,76)$. This was exhibited by an increased production of pro-inflammatory cytokines and the proliferation of $\mathrm{CD} 4^{+} \mathrm{T}$ cells (68). A study in Ugandan children revealed that the production of cytokines by $\mathrm{CD} 4^{+} \mathrm{T}$ cells is influenced by prior exposure to malaria infections. $\mathrm{CD} 4^{+} \mathrm{T}$ cells in more exposed children were shown to produce higher levels of IL-10, while those in less exposed children produced higher levels of $\mathrm{TNF} \alpha$, hence promoting inflammation. The lack of $\mathrm{TNF} \alpha$ production was associated with asymptomatic infections (9). A transcriptomic study in Mali described the activation of pro-inflammatory cytokine (IFN- $\gamma$, TNF, and IL$1 \beta$ ) production as being influenced by prior exposure to malaria, with asymptomatic infections having the least activation of these cytokines (14). Another study in Uganda revealed that frequent exposure to malaria infection causes decreased levels of proinflammatory cytokine (IFN- $\gamma, \mathrm{TNF}$ ) producing $\mathrm{V} \delta 2^{+} \gamma \delta \mathrm{T}$ cells and increased expression of immunoregulatory genes potentially dampening symptom development upon subsequent infections (16). In addition to exposure, age differences have also been suggested to modulate the immune system, with older children having lower anti-inflammatory and pro-inflammatory responses as compared to younger children (15). Lower levels of regulatory $\mathrm{T}$ cells ( $\mathrm{T}$ regs) has also been observed in asymptomatic compared to symptomatic individuals $(77,78)$. Additionally, high levels of $\mathrm{T}$ regs have been associated with increased parasitemia, TGF- $\beta$ production and the development of clinical symptoms $(77,79,80)$. Lower $\mathrm{T}$ reg levels, on the other hand, may result in a decreased risk of developing symptoms, which translates to anti-disease immunity (78).

Unlike in asymptomatic infections, the Fulani ethnic group, who have reduced susceptibility to $P$. falciparum infection compared to sympatric tribes, have a higher ratio of pro-inflammatory to anti-inflammatory cytokines (81). The higher levels of pro-inflammatory cytokines have been implicated in causing the reduced symptomatic cases and parasite densities. In a transcriptomic study of their monocytes, increased upregulation of gene pathways involved in the production of pro-inflammatory cytokines in uninfected Fulani was observed, potentially priming the immune system to respond more effectively to $P$. falciparum infections (82). Thus, it appears that a balance between inflammatory and regulatory cytokines is important in achieving anti-disease immunity.

Antibodies also play a significant role in malaria protection. Seminal studies in monkeys and humans reported a reduction in fever and parasitemia following the passive transfer of serum or IgG antibodies from immune to non-immune subjects with acute malaria $(83,84)$. However, antibody responses to malaria seem to be short lived as exposure to malaria may not lead to the production of sufficient antigen-specific memory B cells (85). In contrast, a study on Swedish travelers previously treated for malaria maintained long-lasting memory B cells for 16 years without subsequent exposure (86). 
TABLE 2 | A list of selected cytokines and immune cells showing their levels as reported in studies from Africa comparing malaria clinical outcome.

\begin{tabular}{|c|c|c|c|c|}
\hline & Levels & Study site & Clinical comparison & References \\
\hline \multirow[t]{4}{*}{$\mathrm{IL}-10$} & High & Uganda & Asymptomatic/symptomatic & (9) \\
\hline & High & Ghana & Asymptomatic/uninfected & $(75)$ \\
\hline & High & Mali & Asymptomatic/febrile & $(18)$ \\
\hline & High & Gabon & Asymptomatic/mild & (90) \\
\hline \multirow[t]{2}{*}{ IFN- $\gamma$} & Low & Uganda & Asymptomatic/febrile & (9) \\
\hline & High & Gabon & Asymptomatic/mild & (90) \\
\hline \multirow[t]{2}{*}{$\mathrm{TNF} \alpha$} & Low & Uganda & Asymptomatic/febrile & $(16)$ \\
\hline & Low & Uganda & Asymptomatic/symptomatic & (9) \\
\hline \multirow[t]{2}{*}{ Tregs } & Low & Uganda & Asymptomatic/febrile & $(77)$ \\
\hline & Low & Ghana & Asymptomatic/symptomatic & (78) \\
\hline $\begin{array}{l}\mathrm{V} \delta 2^{+} \gamma \delta \\
\mathrm{T} \text { cells }\end{array}$ & Low & Uganda & Asymptomatic/febrile & $(16)$ \\
\hline $\begin{array}{l}\text { Natural } \\
\text { killer cells }\end{array}$ & Low & Kenya & Asymptomatic/uninfected & (26) \\
\hline
\end{tabular}

Higher titers of antigen-specific IgG have been observed in asymptomatic individuals compared to individuals with other malaria outcomes (87-89). Furthermore, high antigen-specific antibody responses were associated with high levels of IL10 and IFN- $\gamma$ in Gabonese children with asymptomatic $P$. falciparum infection, suggesting that the antibody response may exert protective immune mechanisms (90). Further studies of immune cells and cytokines (Table 2) are necessary to understand the mechanisms underlying immunomodulation and how this can be applied to confer malaria protection. It is evident that there is a complex interplay of various components of the immune system (Figure 2), and one way of potentially interrogating this complexity is through an "omics" approach.

To add to this already complex immune process, coendemicity of $P$. falciparum and helminths is very common in the tropics resulting in increased chances of co-infection (91). Interactions between the two parasites alter immune responses, thus influencing susceptibility to clinical malaria $(92,93)$. There are conflicting reports on the outcome of these interactions as some studies have reported enhanced severity $(94,95)$, others reduced severity $(96,97)$ yet others have revealed no association between helminth co-infection and malaria outcome $(98,99)$. These observations may be due to differences in the co-infecting helminth species (100), the host's level of immunity to P. falciparum (101) and differences in study design (91). Various helminths elicit different immune responses that have an impact on the immunopathology of malaria as a result of the imbalance between pro-inflammatory and anti-inflammatory cytokines (102). However, there are contradictory reports on cytokine profiles resulting from helminths and P. falciparum co-infection. Co-infection with Schistosoma haematobium in Senegal was shown to offset this balance in an age-dependent manner in children and adults when compared to P. falciparum mono-infections. Co-infected children had higher levels of pro-inflammatory cytokines, IFN- $\gamma$ and TNF- $\alpha$, and were more likely develop febrile malaria, while co-infected adults had higher levels of similar pro-inflammatory cytokines as well as anti-inflammatory cytokines IL-10 and TGF- $\beta$ and were more protected from malaria morbidity (103). In Uganda, IL-10 and IL-6 levels were elevated during $P$. falciparum and soil-borne helminth co-infection, while the level of TGF- $\beta$ was reduced (104). The level of IL-10 was also elevated in asymptomatic $P$. falciparum Malian patients with filaria co-infection while IFN- $\gamma$, TNF- $\alpha$, and IL-17 levels were reduced (105). There is growing evidence that $P$. falciparum and helminth co-infections have a profound effect on the host immune system, preventing the immune clearance of either parasite over the other. Although modulation of pro-inflammatory and anti-inflammatory cytokines responses has been suggested as a possible mechanism, more studies are needed to understand the roles of these cytokines and how other aspects of the immune system are involved.

\section{ASYMPTOMATIC P. falciparum TRANSCRIPTOMICS STUDIES}

A number of studies have examined the transcriptomics of asymptomatic $P$. falciparum infections and revealed interesting findings that add to the current phenotypic knowledge of these infections. The first study compared parasite gene expression patterns between 18 cerebral and 18 asymptomatic malaria infections in Cameroonian children using microarrays. The major difference was observed in genes coding for exported proteins, transcriptional factor proteins, proteins involved in protein transport, variant surface antigen (VSA) proteins such as P. falciparum erythrocyte membrane proteins (PfEMP) and repetitive interspersed family (RIFIN) (5). A more recent study in Gabon compared the host transcriptomic profiles between children with uncomplicated, asymptomatic, severe and cerebral malaria and identified 36 genes, among 4,643 transcripts, which are specifically regulated during asymptomatic infections. These genes are involved in nucleotide binding and RNA processing alluding to gene regulation via chromatin remodeling as a potential mode of maintaining asymptomatic infections (6). Chromatin remodeling changes the chromatin architecture, making condensed genomic DNA accessible to the transcription proteins and thereby regulating gene expression. This was shown to influence activation of immune cells such as monocytes and macrophages (106). It is hypothesized that during asymptomatic infections, chromatin remodeling decreases the expression of immunoglobulin genes leading to reduced antibody mediated responses (6). An opposite effect of chromatin remodeling is observed in the Fulani ethnic group. Chromatin remodeling may have resulted in stronger transcriptional activity in the monocytes leading to a pro-inflammatory state and reduced susceptibility to malaria infections when compared to sympatric ethnic groups (82). Preand post-infection profiles of Malian adults who were either febrile, asymptomatic or naïve were compared. Interestingly, asymptomatic individuals had the least transcriptional changes in gene pathways that are regulated by pro-inflammatory cytokines, 


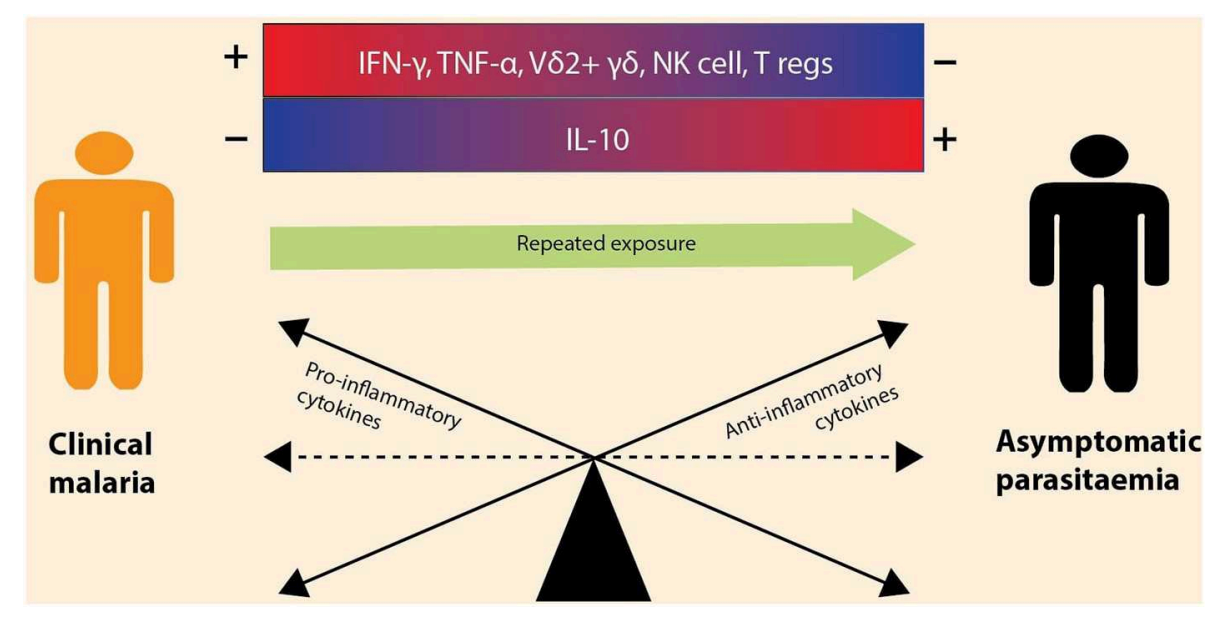

FIGURE 2 | Immune modulation during asymptomatic vs. symptomatic malaria infections. The outcome of a malaria infection is influenced by the balance between anti-inflammatory and pro-inflammatory cytokines. Clinical malaria is the result of elevated (+) production of pro-inflammatory cytokines (e.g., IFN- $\gamma$, TNF- $\alpha)$ and increased levels of immune cells (e.g., V $\delta 2^{+} \gamma \delta$, NK cells, and T regs) and the downregulation (-) of anti-inflammatory cytokines (e.g., IL-10). However, with repeated malaria exposure, the immune balance shifts toward an increased production of anti-inflammatory cytokines, leading to asymptomatic infection. The cytokines are encoded by immune genes, thus differential expression of these genes depicts that there is a balance between anti-inflammatory and pro-inflammatory cytokines.

IFN- $\gamma$, TNF, and IL-1 $\beta$ (14). This was probably caused by the downregulation of genes encoding pro-inflammatory cytokines, as observed in their lower levels in individuals with frequent exposure to P. falciparum in Mali (18). Chronic exposure to $P$. falciparum was shown to cause increased expression of immunoregulatory genes in $\mathrm{V} \delta 2^{+} \mathrm{T}$ cells in Ugandan children (9). The results from the various transcriptomic studies in asymptomatic infections tend to agree that gene regulation mechanisms, either transcription factors or changes in the chromatin structure, may be involved in regulating inflammatory mechanisms that maintain malaria infections in the asymptomatic state. This can be confirmed by studying chromatin accessibility of gene regions that encode inflammatory regulators. Various techniques have been developed to assess genome-wide chromatin accessibility, with the Assay for Transposase-Accessible Chromatin using sequencing (ATACseq) proving to be the most effective (107). This technique has been applied in examining chromatin accessibility in $P$. falciparum and revealed insights into how the accessibility of specific transcriptome regulatory regions, i.e., promoter regions, are directly associated with an abundance of their corresponding transcripts $(108,109)$. The identification of regulatory regions that regulate expression of inflammatory genes in asymptomatic infections is important, as it would improve our understanding of how anti-disease immunity is maintained and reveal regions that can be targeted to achieve anti-parasite immunity and potentially, sterilizing immunity.

\section{FUTURE PERSPECTIVES FOR ASYMPTOMATIC STUDIES}

Asymptomatic malaria appears to be driven by host immunity, such that following multiple exposures to symptomatic infections an individual's immune system is potentially primed to control symptoms. Initially, at a young age, individuals in malaria endemic areas are likely to have high pro-inflammatory responses to control infection, which also results in the clinical manifestation of disease. With age, due to multiple exposure to infection, the immune system is perhaps trained and the balance shifts to a predominance of anti-inflammatory responses to control the infection with no clinical signs of disease, to a point that infection is tolerated and parasitemia is maintained. Since immunity to malaria is not sterile, there appears to be a trade-off between anti-parasite and anti-disease immunity, with the latter dominating in asymptomatic infections, where the focus is controlling disease rather than clearing parasites. This compromise in host immunity to control disease and not clear parasites is likely driven by the anti-inflammatory immune response. A transcriptomic approach to analyzing the cells and cytokines involved in the process would provide the necessary insight to unraveling the role of both anti- and pro-inflammatory responses to asymptomatic infections.

Though there is still a gap in our understanding of how the parasite remains in an asymptomatic state in individuals from malaria endemic areas, various studies have implicated genes responsible for gene regulation and chromatin remodeling and it is still unclear how host immunity is involved. Highthroughput studies are needed to understand differential gene expression in immune cells that have shown differential activity in asymptomatic vs. symptomatic or uninfected states (5). Recently, single cell transcriptomics has emerged as a new approach in transcriptomic studies that characterizes individual cells, improving our ability to study cell to cell variability, unlike the conventional transcriptome method that assumes and treats cells from a certain tissue as homogenous (110). Reid et al. (111) used this technique to show transcription variation across all stages of the parasite life cycle and how genes involved in immune 
evasion aid the parasite in transiting from the asexual stage in humans to its sexual stage in the mosquito (111). Properly designed asymptomatic $P$. falciparum single cell RNA-seq studies of individual immune cells and parasites with good criteria for defining asymptomatic infections hold the key to understanding these chronic and debilitating infections as well as host pathogen interactions in general.

Furthermore, there is a need for a consensus on how asymptomatic infections are defined. Longitudinal cohorts or follow ups over a period of 6 weeks, 4 weeks prior to the asymptomatic case and 2 weeks following the case, with no history or evidence of the individual having taken antimalarials and no evidence of fever $48 \mathrm{~h}$ before and after the case, are likely to be the most feasible approach to defining an asymptomatic infection. More sensitive tools for defining the presence of parasitemia to minimize missing sub-patent infections requires methods such as PCR, LAMP, or the newly described hemozoin sensing assay (33). With a clear definition of asymptomatic infections, further downstream analyses become possible. Exploiting next generation sequencing platforms to conduct amplicon deep sequencing and RNA-Seq has the potential to allow for a comprehensive analysis of asymptomatic infections to a scale not previously explored. The scale to which COI can be defined using amplicon deep sequencing improves the accuracy of determining COI in asymptomatic infections, the impact of COI on the risk of developing febrile disease and immunity. RNA-seq promises to unravel the complexities of the host immune response to malaria infection, describing at the transcriptomic level which molecules are likely to be involved in particular processes of controlling infection or, in the case of asymptomatic infections, maintaining parasitemia with no clinical symptoms. Of interest in this review was the role of anti- and pro-inflammatory cytokines in determining the course of infection. A focused analysis of transcripts related

\section{REFERENCES}

1. World Health Organization. World Malaria Report 2018. Global Malaria Programme; Geneva: World Health Organization (WHO) (2018).

2. World Health Organization. World Malaria Report 2016. Geneva: World Health Organization (WHO) (2016).

3. Snow RW, Guerra CA, Noor AM, Myint HY, Simon I. The global distribution of clinical episodes of Plasmodium falciparum malaria. Nature. (2005) 434:214-7. doi: 10.1038/nature03342

4. Laishram DD, Sutton PL, Nanda N, Sharma VL, Sobti RC, Carlton JM, et al. The complexities of malaria disease manifestations with a focus on asymptomatic malaria. Malar J. (2012) 11:29. doi: 10.1186/1475-2875-11-29

5. Almelli T, Nuel G, Bischoff E, Aubouy A, Elati M, Wang CW, et al. Differences in gene transcriptomic pattern of Plasmodium falciparum in children with cerebral malaria and asymptomatic carriers. PLoS ONE. (2014) 9:e114401. doi: 10.1371/journal.pone.0114401

6. Boldt ABW, van Tong H, Grobusch MP, Kalmbach Y, Dzeing Ella A, Kombila M, et al. The blood transcriptome of childhood malaria. EBioMedicine. (2019) 40:614-25. doi: 10.1016/j.ebiom.2018. 12.055

7. Othoro C, Lal AA, Nahlen B, Koech D, Orago ASS, Udhayakumar V. A low interleukin-10 tumor necrosis factor- $\alpha$ ratio is associated with malaria anemia in children residing in a holoendemic malaria region in western Kenya. J Infect Dis. (1999) 179:279-82. doi: 10.1086/ 314548 to these pathways would provide a better understanding of the role cytokines play in regulating the immune system and influencing malaria outcome. Notably, a better understanding of chromatin remodeling pathways is required to determine whether they are associated with particular gene transcripts, and ATAC-Seq will allow further interrogation of these pathways.

\section{AUTHOR CONTRIBUTIONS}

$\mathrm{KK}$ and LO-O conceived, drafted, and reviewed the manuscript. KW drafted and reviewed the manuscript.

\section{FUNDING}

This work was supported through the DELTAS Africa Initiative (Grant No. DEL-15-003), an independent funding scheme of the African Academy of Sciences (AAS) Alliance for Accelerating Excellence in Science in Africa (AESA) and supported by the New Partnership for Africa's Development Planning and Coordinating Agency (NEPAD Agency) with funding from the Wellcome Trust and the UK government, DELGEME Grant 107740/Z/15/Z to support KK and IDeAL Grant No. 107769/Z/10/Z to support KW. The views expressed in this publication are those of the author(s) and not necessarily those of AAS, NEPAD Agency, Wellcome Trust or the UK government. There was also support from a Wellcome Trust Intermediate Fellowship (Grant No. 107568/Z/15/Z awarded to LO-O).

\section{ACKNOWLEDGMENTS}

We thank Dr. Eunice Nduati for her helpful comments on the manuscript and the Director of the Kenya Medical Research Institute, Dr. Yeri Kombe, for permission to publish this article.

8. Udomsangpetch R, Looareesuwan S, Viriyavejakul P, Pongponratn E, Riganti M, Chivapat S, et al. Involvement of cytokines in the histopathology of cerebral malaria. Am J Trop Med Hyg. (1997) 57:501-6. doi: 10.4269/ajtmh.1997.57.501

9. Jagannathan P, Eccles-James I, Bowen K, Nankya F, Auma A, Wamala S, et al. IFN $\gamma / \mathrm{IL}-10$ co-producing cells dominate the CD4 response to malaria in highly exposed children. PLoS Pathog. (2014) 10:e1003864. doi: 10.1371/journal.ppat.1003864

10. Severe falciparum malaria. World Health Organization, communicable diseases cluster. Trans R Soc Trop Med Hyg. (2000) 94 (Suppl. 1):S190. doi: 10.1016/S0035-9203(00)90300-6

11. Lindblade KA, Steinhardt L, Samuels A, Kachur SP, Slutsker L. The silent threat: asymptomatic parasitemia and malaria transmission. Expert Rev Anti Infect Ther. (2013) 11:623-39. doi: 10.1586/eri.13.45

12. Ademolue TW, Awandare GA. Evaluating antidisease immunity to malaria and implications for vaccine design. Immunology. (2018) 153:42334. doi: 10.1111/imm.12877

13. Idris ZM, Chan CW, Kongere J, Gitaka J, Logedi J, Omar A, et al. High and heterogeneous prevalence of asymptomatic and sub-microscopic malaria infections on islands in Lake Victoria, Kenya. Sci Rep. (2016) 6:36958. doi: 10.1038/srep36958

14. Tran TM, Jones MB, Ongoiba A, Bijker EM, Schats R, Venepally P, et al. Transcriptomic evidence for modulation of host inflammatory responses during febrile Plasmodium falciparum malaria. Sci Rep. (2016) 6:31291. doi: 10.1038/srep31291 
15. Farrington L, Vance H, Rek J, Prahl M, Jagannathan P, Katureebe A, et al. Both inflammatory and regulatory cytokine responses to malaria are blunted with increasing age in highly exposed children. Malar J. (2017) 16:499. doi: 10.1186/s12936-017-2148-6

16. Jagannathan P, Kim CC, Greenhouse B, Nankya F, Bowen K, Eccles-James I, et al. Loss and dysfunction of $\mathrm{V} \delta 2^{+} \gamma \delta \mathrm{T}$ cells are associated with clinical tolerance to malaria. Sci Transl Med. (2014) 6:251ra117. doi: 10.1126/scitranslmed.3009793

17. Portugal S, Tran TM, Ongoiba A, Bathily A, Li S, Doumbo S, et al. Treatment of chronic asymptomatic Plasmodium falciparum infection does not increase the risk of clinical malaria upon reinfection. Clin Infect Dis. (2017) 64:64553. doi: 10.1093/cid/ciw849

18. Portugal S, Moebius J, Skinner J, Doumbo S, Doumtabe D, Kone Y, et al. Exposure-dependent control of malaria-induced inflammation in children. PLoS Pathog. (2014) 10:e1004079. doi: 10.1371/journal.ppat.1004079

19. Botwe AK, Asante KP, Adjei G, Assafuah S, Dosoo D, Owusu-Agyei S. Dynamics in multiplicity of Plasmodium falciparum infection among children with asymptomatic malaria in central Ghana. BMC Genet. (2017) 18:67. doi: 10.1186/s12863-017-0536-0

20. Wamae K, Wambua J, Nyangweso G, Mwambingu G, Osier F, Ndung'u F, et al. Transmission and age impact the risk of developing febrile malaria in children with asymptomatic Plasmodium falciparum parasitemia. J Infect Dis. (2018) 219:936-44. doi: 10.1093/infdis/jiy591

21. Ashley EA, Pyae Phyo A, Woodrow CJ. Malaria. Lancet. (2018) 391:160821. doi: 10.1016/S0140-6736(18)30324-6

22. Vasoo S, Pritt BS. Molecular diagnostics and parasitic disease. Clin Lab Med. (2013) 33:461-503. doi: 10.1016/j.cll.2013.03.008

23. Alves FP, Durlacher RR, Menezes MJ, Krieger H, Silva LHP, Camargo EP. High prevalence of asymptomatic Plasmodium vivax and Plasmodium falciparum infections in native Amazonian populations. Am J Trop Med Hyg. (2002) 66:641-8. doi: 10.4269/ajtmh.2002.66.641

24. Nsobya SL, Parikh S, Kironde F, Lubega G, Kamya MR, Rosenthal PJ, et al. Molecular evaluation of the natural history of asymptomatic parasitemia in Ugandan children. J Infect Dis. (2004) 189:2220-6. doi: 10.1086/ 421281

25. Barbosa S, Gozze AB, Lima NF, Batista CL, Bastos MdS, Nicolete VC, et al. Epidemiology of disappearing Plasmodium vivax malaria: a case study in rural Amazonia. PLoS Negl Trop Dis. (2014) 8:e3109. doi: 10.1371/journal.pntd.0003109

26. Kijogi C, Kimura D, Bao LQ, Nakamura R, Chadeka EA, Cheruiyot NB, et al. Modulation of immune responses by Plasmodium falciparum infection in asymptomatic children living in the endemic region of Mbita, western Kenya. Parasitol Int. (2018) 67:284-93. doi: 10.1016/j.parint.2018.01.001

27. Sattabongkot J, Suansomjit C, Nguitragool W, Sirichaisinthop J, Warit S, Tiensuwan M, et al. Prevalence of asymptomatic Plasmodium infections with sub-microscopic parasite densities in the northwestern border of Thailand: a potential threat to malaria elimination. Malar J. (2018) 17:329. doi: 10.1186/s12936-018-2476-1

28. Krampa FD, Aniweh Y, Awandare GA, Kanyong P. Recent progress in the development of diagnostic tests for malaria. Diagnostics. (2017) 7:E54. doi: 10.3390/diagnostics7030054

29. Jain P, Chakma B, Patra S, Goswami P. Potential biomarkers and their applications for rapid and reliable detection of malaria. Biomed Res Int. (2014) 2014:852645. doi: 10.1155/2014/852645

30. Coronado LM, Nadovich CT, Spadafora C. Malarial hemozoin: from target to tool. Biochim Biophys Acta. (2014) 1840:203241. doi: 10.1016/j.bbagen.2014.02.009

31. Olivier M, Van Den Ham K, Shio MT, Kassa FA, Fougeray S. Malarial pigment hemozoin and the innate inflammatory response. Front Immunol. (2014) 5:25. doi: 10.3389/fimmu.2014.00025

32. Ihekwereme CP, Esimone CO, Nwanegbo EC. Hemozoin inhibition and control of clinical malaria. Adv Pharmacol Sci. (2014) 2014:984150. doi: 10.1155/2014/984150

33. Rifaie-Graham O, Pollard J, Raccio S, Balog S, Rusch S, Hernández-Castañeda MA, et al. Hemozoin-catalyzed precipitation polymerization as an assay for malaria diagnosis. Nat Commun. (2019) 10:1369. doi: 10.1038/s41467-019-09122-z
34. Galatas B, Bassat Q, Mayor A. Malaria parasites in the asymptomatic: looking for the hay in the haystack. Trends Parasitol. (2016) 32:296308. doi: $10.1016 /$ j.pt.2015.11.015

35. Newby G, Hwang J, Koita K, Chen I, Greenwood B, von Seidlein L, et al. Review of mass drug administration for malaria and its operational challenges. Am J Trop Med Hyg. (2015) 93:125-34. doi: 10.4269/ajtmh.14-0254

36. Sturrock HJW, Hsiang MS, Cohen JM, Smith DL, Greenhouse $\mathrm{B}$, Bousema $\mathrm{T}$, et al. Targeting asymptomatic malaria infections: active surveillance in control and elimination. PLoS Med. (2013) 10:e1001467. doi: 10.1371/journal.pmed.1001467

37. Smith T, Felger I, Tanner M, Beck HP. Premunition in Plasmodium falciparum infection: insights from the epidemiology of multiple infections. Trans $R$ Soc Trop Med Hyg. (1999) 93 (Suppl. 1):59-64. doi: 10.1016/S0035-9203(99)90329-2

38. Tiono AB, Ouédraogo A, Ogutu B, Diarra A, Coulibaly S, Gansané A, et al. A controlled, parallel, cluster-randomized trial of community-wide screening and treatment of asymptomatic carriers of Plasmodium falciparum in Burkina Faso. Malar J. (2013) 12:79. doi: 10.1186/1475-2875-12-79

39. Njama-Meya D, Kamya MR, Dorsey G. Asymptomatic parasitemia as a risk factor for symptomatic malaria in a cohort of Ugandan children. Trop Med Int Heal. (2004) 9:862-8. doi: 10.1111/j.1365-3156.2004.01277.x

40. Roper C, Richardson W, Elhassan IM, Giha H, Hviid L, Satti GMH, et al. Seasonal changes in the Plasmodium falciparum population in individuals and their relationship to clinical malaria: a longitudinal study in a Sudanese village. Parasitology. (1998) 116:501-10. doi: 10.1017/S0031182098002650

41. Ofosu-Okyere A, Mackinnon MJ, Sowa MP, Koram KA, Nkrumah F, Osei YD, et al. Novel Plasmodium falciparum clones and rising clone multiplicities are associated with the increase in malaria morbidity in Ghanaian children during the transition into the high transmission season. Parasitology. (2001) 123:113-23. doi: 10.1017/S0031182001008162

42. Kun JFJ, Missinou MA, Lell B, Sovric M, Knoop H, Bojowald B, et al. New emerging Plasmodium falciparum genotypes in children during the transition phase from asymptomatic parasitemia to malaria. Am J Trop Med Hyg. (2002) 66:653-8. doi: 10.4269/ajtmh.2002.66.653

43. Babiker HA, Ranford-Cartwright LC, Currie D, Charlwood JD, Billingsley $\mathrm{P}$, Teuscher $\mathrm{T}$, et al. Random mating in a natural population of the malaria parasite Plasmodium falciparum. Parasitology. (1994) 109:413. doi: 10.1017/S0031182000080665

44. Babiker HA, Abdel-Muhsin AA, Hamad A, Mackinnon MJ, Hill WG, Walliker D. Population dynamics of Plasmodium falciparum in an unstable malaria area of eastern Sudan. Parasitology. (2000) 120 (Pt 2):10511. doi: 10.1017/S0031182099005387

45. Magesa SM, Mdira KY, Babiker HA, Alifrangis M, Färnert A, Simonsen $\mathrm{PE}$, et al. Diversity of Plasmodium falciparum clones infecting children living in a holoendemic area in north-eastern Tanzania. Acta Trop. (2002) 84:83-92. doi: 10.1016/S0001-706X(02)00179-1

46. Agyeman-Budu A, Brown C, Adjei G, Adams M, Dosoo D, Dery D, et al. Trends in multiplicity of Plasmodium falciparum infections among asymptomatic residents in the middle belt of Ghana. Malar J. (2013) 12:22. doi: 10.1186/1475-2875-12-22

47. Bereczky S, Liljander A, Rooth I, Faraja L, Granath F, Montgomery SM, et al. Multiclonal asymptomatic Plasmodium falciparum infections predict a reduced risk of malaria disease in a Tanzanian population. Microbes Infect. (2007) 9:103-10. doi: 10.1016/j.micinf.2006.10.014

48. Rono J, Osier FHA, Olsson D, Montgomery S, Mhoja L, Rooth I, et al. Breadth of anti-merozoite antibody responses is associated with the genetic diversity of asymptomatic Plasmodium falciparum infections and protection against clinical malaria. Clin Infect Dis. (2013) 57:1409-16. doi: 10.1093/cid/cit556

49. Amodu OK, Adeyemo AA, Ayoola OO, Gbadegesin RA, Orimadegun AE, Akinsola AK, et al. Genetic diversity of the msp-1 locus and symptomatic malaria in south-west Nigeria. Acta Trop. (2005) 95:22632. doi: 10.1016/j.actatropica.2005.06.017

50. Amodu OK, Oyedeji SI, Ntoumi F, Orimadegun AE, Gbadegesin RA, Olumese PE, et al. Complexity of the msp2 locus and the severity of childhood malaria, in south-western Nigeria. Ann Trop Med Parasitol. (2008) 102:95-102. doi: 10.1179/136485908X252340 
51. Felger I, Smith T, Edoh D, Kitua A, Alonso P, Tanner M, et al. Multiple Plasmodium falciparum infections in Tanzanian infants. Trans $R$ Soc Trop Med Hyg. (1999) 93:29-34. doi: 10.1016/S0035-9203(99)90324-3

52. Mayor A, Saute F, Aponte JJ, Almeda J, Gómez-Olivé FX, Dgedge M, et al. Plasmodium falciparum multiple infections in Mozambique, its relation to other malariological indices and to prospective risk of malaria morbidity. Trop Med Int Heal. (2003) 8:3-11. doi: 10.1046/j.1365-3156.2003.00968.x

53. Beck HP, Felger I, Huber W, Steiger S, Smith T, Weiss N, et al. Analysis of multiple Plasmodium falciparum infections in Tanzanian children during the phase III trial of the malaria vaccine SPf66. J Infect Dis. (1997) 175:9216. doi: 10.1086/513991

54. Snounou G. Genotyping of Plasmodium spp.: nested PCR. In: Doolan DL, editor. Malaria Methods and Protocols. New Jersey, NY: Humana Press (2002). p. 103-16. doi: 10.1385/1-59259-271-6:103

55. Liljander A, Wiklund L, Falk N, Kweku M, Mrtensson A, Felger I, et al. Optimization and validation of multi-coloured capillary electrophoresis for genotyping of Plasmodium falciparum merozoite surface proteins ( $\mathrm{msp} 1$ and 2). Malar J. (2009) 8:1-14. doi: 10.1186/1475-2875-8-78

56. Juliano JJ, Taylor SM, Meshnick SR. Polymerase chain reaction adjustment in antimalarial trials: molecular malarkey? J Infect Dis. (2009) 200:57. doi: 10.1086/599379

57. Juliano JJ, Porter K, Mwapasa V, Sem R, Rogers WO, Ariey F, et al. Exposing malaria in-host diversity and estimating population diversity by capturerecapture using massively parallel pyrosequencing. Proc Natl Acad Sci USA. (2010) 107:20138-43. doi: 10.1073/pnas.1007068107

58. Lerch A, Koepfli C, Hofmann NE, Kattenberg JH, Rosanas-Urgell A, Betuela I, et al. Longitudinal tracking and quantification of individual Plasmodium falciparum clones in complex infections. Sci Rep. (2019) 9:3333. doi: 10.1038/s41598-019-39656-7

59. Mideo N, Kennedy DA, Carlton JM, Bailey JA, Juliano JJ, Read AF. Ahead of the curve: next generation estimators of drug resistance in malaria infections. Trends Parasitol. (2013) 29:321-8. doi: 10.1016/j.pt.2013.05.004

60. Bull PC, Marsh K. The role of antibodies to Plasmodium falciparum-infectederythrocyte surface antigens in naturally acquired immunity to malaria. Trends Microbiol. (2002) 10:55-8. doi: 10.1016/S0966-842X(01)02278-8

61. Day KP, Marsh K. Naturally acquired immunity to Plasmodium falciparum. Immunol Today. (1991) 12:A68-71. doi: 10.1016/S0167-5699(05)80020-9

62. Greenwood BM, Palit A, Bradley-Moore A, Bryceson ADM. Immunosuppression in children with malaria. Lancet. (1972) 299:169-72. doi: 10.1016/S0140-6736(72)90569-7

63. Bediako Y, Adams R, Reid AJ, Valletta JJ, Ndungu FM, Sodenkamp $\mathrm{J}$, et al. Repeated clinical malaria episodes are associated with modification of the immune system in children. BMC Med. (2019) 17:60. doi: 10.1186/s12916-019-1292-y

64. Roucher C, Rogier C, Dieye-Ba F, Sokhna C, Tall A, Trape JF. Changing malaria epidemiology and diagnostic criteria for Plasmodium falciparum clinical malaria. PLoS ONE. (2012) 7:e46188. doi: 10.1371/journal.pone.0046188

65. Ladeia-Andrade S, Ferreira MU, de Carvalho ME, Curado I, Coura JR. Age-dependent acquisition of protective immunity to malaria in riverine populations of the Amazon Basin of Brazil. Am J Trop Med Hyg. (2009) 80:452-9. doi: 10.4269/ajtmh.2009.80.452

66. Medzhitov R, Schneider DS, Soares MP. Disease tolerance as a defense strategy. Science. (2012) 335:936-41. doi: 10.1126/science.1214935

67. de Mendonça VR, Barral-Netto M. Immunoregulation in human malaria: the challenge of understanding asymptomatic infection. Mem Inst Oswaldo Cruz. (2015) 110:945-55. doi: 10.1590/0074-02760150241

68. Bediako Y, Ngoi JM, Nyangweso G, Wambua J, Opiyo M, Nduati EW, et al. The effect of declining exposure on $\mathrm{T}$ cell-mediated immunity to Plasmodium falciparum - an epidemiological "natural experiment." BMC Med. (2016) 14:143. doi: 10.1186/s12916-016-0683-6

69. Kumar R, Ng S, Engwerda C. The role of IL-10 in malaria: a double edged sword. Front Immunol. (2019) 10:229. doi: 10.3389/fimmu.2019. 00229

70. Angulo I, Fresno M. Cytokines in the pathogenesis of and protection against malaria. Clin Diagn Lab Immunol. (2002) 9:1145-52. doi: 10.1128/CDLI.9.6.1145-1152.2002
71. Malaguarnera L, Musumeci S. The immune response to Plasmodium falciparum malaria. Lancet Infect Dis. (2002) 2:472-8. doi: 10.1016/S1473-3099(02)00344-4

72. Lyke KE, Burges R, Cissoko Y, Sangare L, Dao M, Diarra I, et al. Serum levels of the proinflammatory cytokines interleukin-1 beta (IL1), IL-6, IL-8, IL-10, tumor necrosis factor alpha, and IL-12(p70) in malian children with severe Plasmodium falciparum malaria and matched uncomplicated malaria or healthy controls. Infect Immun. (2004) 72:56307. doi: 10.1128/IAI.72.10.5630-5637.2004

73. Butler NS, Harris TH, Blader IJ. Regulation of immunopathogenesis during Plasmodium and Toxoplasma infections: more parallels than distinctions? Trends Parasitol. (2013) 29:593-602. doi: 10.1016/j.pt.2013.10.002

74. Findlay EG, Greig R, Stumhofer JS, Hafalla JCR, de Souza JB, Saris CJ, et al. Essential role for IL-27 receptor signaling in prevention of Th1mediated immunopathology during malaria infection. J Immunol. (2010) 185:2482-92. doi: 10.4049/jimmunol.0904019

75. Wilson NO, Bythwood T, Solomon W, Jolly P, Yatich N, Jiang Y, et al. Elevated levels of IL-10 and G-CSF associated with asymptomatic malaria in pregnant women. Infect Dis Obstet Gynecol. (2010) 2010:317430. doi: 10.1155/2010/317430

76. Deloron P, Chougnet C. Is immunity to malaria really short-lived? Parasitol Today. (1992) 8:375-8. doi: 10.1016/0169-4758(92)90174-Z

77. Boyle MJ, Jagannathan P, Farrington LA, Eccles-James I, Wamala S, McIntyre TI, et al. Decline of FoxP3 + regulatory CD4 T cells in peripheral blood of children heavily exposed to malaria. PLoS Pathog. (2015) 11:e1005041. doi: 10.1371/journal.ppat.1005041

78. Frimpong A, Kusi KA, Tornyigah B, Ofori MF, Ndifon W. Characterization of $\mathrm{T}$ cell activation and regulation in children with asymptomatic Plasmodium falciparum infection. Malar J. (2018) 17:263. doi: 10.1186/s12936-018-2410-6

79. Minigo G, Woodberry T, Piera KA, Salwati E, Tjitra E, Kenangalem E, et al. Parasite-dependent expansion of TNF receptor II-positive regulatory T cells with enhanced suppressive activity in adults with severe malaria. PLoS Pathog. (2009) 5:e1000402. doi: 10.1371/journal.ppat.1000402

80. Walther M, Tongren JE, Andrews L, Korbel D, King E, Fletcher H, et al. Upregulation of TGF- $\beta$, FOXP3, and $\mathrm{CD} 4{ }^{+} \mathrm{CD} 25^{+}$regulatory $\mathrm{T}$ cells correlates with more rapid parasite growth in human malaria infection. Immunity. (2005) 23:287-96. doi: 10.1016/j.immuni.2005.08.006

81. Boström S, Giusti P, Arama C, Persson J-O, Dara V, Traore B, et al. Changes in the levels of cytokines, chemokines and malaria-specific antibodies in response to Plasmodium falciparum infection in children living in sympatry in Mali. Malar J. (2012) 11:109. doi: 10.1186/1475-2875-11-109

82. Sanou GS, Qu Y, Quin JE, Bujila I, Che M, Homann MV, et al. Major transcriptional changes observed in the Fulani, an ethnic group less susceptible to malaria. (2017) 6:e29156. doi: 10.7554/eLife.29156

83. Cohen S, McGregor IA, Carrington S. Gamma-globulin and acquired immunity to human malaria. Nature. (1961) 192:7337. doi: 10.1038/192733a0

84. Mshana RN, Boulandi J, Mshana NM, Mayombo J, Mendome G. Cytokines in the pathogenesis of malaria: levels of IL-I beta, IL-4, IL-6, TNF-alpha and IFN-gamma in plasma of healthy individuals and malaria patients in a holoendemic area. J Clin Lab Immunol. (1991) 34:131-9.

85. Dorfman JR, Bejon P, Ndungu FM, Langhorne J, Kortok MM, Lowe BS, et al. B cell memory to 3 Plasmodium falciparum blood-stage antigens in a malaria-endemic area. J Infect Dis. (2005) 191:1623-30. doi: 10.1086/429671

86. Ndungu FM, Lundblom K, Rono J, Illingworth J, Eriksson S, Färnert A. Longlived Plasmodium falciparum specific memory B cells in naturally exposed Swedish travelers. Eur J Immunol. (2013) 43:2919. doi: 10.1002/eji.201343630

87. Kinyanjui SM, Mwangi T, Bull PC, Newbold CI, Marsh K. Protection against clinical malaria by heterologous immunoglobulin $\mathrm{G}$ antibodies against malaria-infected erythrocyte variant surface antigens requires interaction with asymptomatic infections. J Infect Dis. (2004) 190:152733. doi: 10.1086/424675

88. Moormann AM, Sumba PO, Chelimo K, Fang H, Tisch DJ, Dent AE, et al. Humoral and cellular immunity to Plasmodium falciparum merozoite surface protein 1 and protection from infection with blood-stage parasites. $J$ Infect Dis. (2013) 208:149-58. doi: 10.1093/infdis/jit134 
89. Braga EM, Barros RM, Reis TA, Fontes CJF, Morais CG, Martins MS, et al. Association of the IgG response to Plasmodium falciparum merozoite protein (C-terminal $19 \mathrm{kD}$ ) with clinical immunity to malaria in the Brazilian Amazon region. Am J Trop Med Hyg. (2002) 66:4616. doi: 10.4269/ajtmh.2002.66.461

90. Guiyedi V, Bécavin C, Herbert F, Gray J, Cazenave P-A, Kombila M, et al. Asymptomatic Plasmodium falciparum infection in children is associated with increased auto-antibody production, high IL-10 plasma levels and antibodies to merozoite surface protein 3. Malar J. (2015) 14:162. doi: 10.1186/s12936-015-0658-7

91. Mwangi TW, Bethony JM, Brooker S. Malaria and helminth interactions in humans: an epidemiological viewpoint. Ann Trop Med Parasitol. (2006) 100:551-70. doi: 10.1179/136485906X118468

92. Druilhe P, Tall A, Sokhna C. Worms can worsen malaria: towards a new means to roll back malaria? Trends Parasitol. (2005) 21:35962. doi: 10.1016/j.pt.2005.06.011

93. Vaumourin E, Vourc'h G, Gasqui P, Vayssier-Taussat M. The importance of multiparasitism: examining the consequences of coinfections for human and animal health. Parasit Vectors. (2015) 8:545. doi: 10.1186/s13071-015-1167-9

94. Midzi N, Mtapuri-Zinyowera S, Mapingure MP, Sangweme D, Chirehwa MT, Brouwer KC, et al. Consequences of polyparasitism on anaemia among primary school children in Zimbabwe. Acta Trop. (2010) 115:10311. doi: 10.1016/j.actatropica.2010.02.010

95. Wilson S, Vennervald BJ, Kadzo H, Ireri E, Amaganga C, Booth M, et al. Hepatosplenomegaly in Kenyan schoolchildren: exacerbation by concurrent chronic exposure to malaria and Schistosoma mansoni infection. Trop Med Int Heal. (2007) 12:1442-9. doi: 10.1111/j.1365-3156.2007.01950.x

96. Hürlimann E, Houngbedji CA, Yapi RB, N’Dri PB, Silué KD, Ouattara M, et al. Antagonistic effects of Plasmodium-helminth co-infections on malaria pathology in different population groups in Côte d'Ivoire. PLoS Negl Trop Dis. (2019) 13:e0007086. doi: 10.1371/journal.pntd.0007086

97. Cot M, Garcia A, Le Hesran JY, Lemaitre M, Watier L, Briand V. Coinfection with Plasmodium falciparum and Schistosoma haematobium: additional evidence of the protective effect of schistosomiasis on malaria in Senegalese children. Am J Trop Med Hyg. (2014) 90:329-34. doi: 10.4269/ajtmh.12-0431

98. Lo AC, Faye B, Gyan BA, Amoah LE. Plasmodium and intestinal parasite perturbations of the infected host's inflammatory responses: a systematic review. Parasit Vectors. (2018) 11:387. doi: 10.1186/s13071-018-2948-8

99. Ojurongbe O, Adegbayi AM, Bolaji OS, Akindele AA, Adefioye OA, Adeyeba OA. Asymptomatic falciparum malaria and intestinal helminths co-infection among school children in Osogbo, Nigeria. J Res Med Sci. (2011) 16:680-6.

100. Shapiro AE, Tukahebwa EM, Kasten J, Clarke SE, Magnussen P, Olsen A, et al. Epidemiology of helminth infections and their relationship to clinical malaria in southwest Uganda. Trans R Soc Trop Med Hyg. (2005) 99:18-24. doi: 10.1016/j.trstmh.2004.02.006

101. Mboera LEG, Senkoro KP, Rumisha SF, Mayala BK, Shayo EH, Mlozi MRS. Plasmodium falciparum and helminth coinfections among schoolchildren in relation to agro-ecosystems in Mvomero District, Tanzania. Acta Trop. (2011) 120:95-102. doi: 10.1016/j.actatropica.2011.06.007
102. Maizels RM, Balic A, Gomez-Escobar N, Nair M, Taylor MD, Allen JE. Helminth parasites - masters of regulation. Immunol Rev. (2004) 201:89116. doi: 10.1111/j.0105-2896.2004.00191.x

103. Diallo TO, Remoue F, Schacht AM, Charrier N, Dompnier J, Pillet S, et al. Schistosomiasis co-infection in humans influences inflammatory markers in uncomplicated Plasmodium falciparum malaria. (2005) 26:3659. doi: 10.1111/j.0141-9838.2004.00719.x

104. Bwanika R, Kato CD, Welishe J, Mwandah DC. Cytokine profiles among patients co-infected with Plasmodium falciparum malaria and soil borne helminths attending Kampala International University Teaching Hospital, in Uganda. Allergy Asthma Clin Immunol. (2018) 14:10. doi: 10.1186/s13223-018-0235-Z

105. Metenou S, Dembele B, Konate S, Dolo H, Coulibaly YI, Diallo AA, et al. Filarial infection suppresses malaria-specific multifunctional Th1 and Th17 responses in malaria and filarial coinfections. J Immunol. (2011) 186:472533. doi: 10.4049/jimmunol.1003778

106. Schultze JL. Chromatin remodeling in monocyte and macrophage activation. Adv Protein Chem Struct Biol. (2017) 106:115. doi: 10.1016/bs.apcsb.2016.09.001

107. Buenrostro JD, Giresi PG, Zaba LC, Chang HY, Greenleaf WJ. Transposition of native chromatin for fast and sensitive epigenomic profiling of open chromatin, DNA-binding proteins and nucleosome position. Nat Methods. (2013) 10:1213-8. doi: 10.1038/nmeth.2688

108. Ruiz JL, Tena JJ, Bancells C, Cortés A, Gómez-Skarmeta JL, GómezDíaz E. Characterization of the accessible genome in the human malaria parasite Plasmodium falciparum. Nucleic Acids Res. (2018) 46:941431. doi: 10.1093/nar/gky643

109. Toenhake CG, Fraschka SA-K, Vijayabaskar MS, Westhead DR, van Heeringen SJ, Bártfai R. Chromatin accessibility-based characterization of the gene regulatory network underlying Plasmodium falciparum blood-stage development. Cell Host Microbe. (2018) 23:557-69.e9. doi: 10.1016/j.chom.2018.03.007

110. Hwang B, Lee JH, Bang D. Single-cell RNA sequencing technologies and bioinformatics pipelines. Exp Mol Med. (2018) 50:96. doi: 10.1038/s12276-018-0071-8

111. Reid AJ, Talman AM, Bennett HM, Gomes AR, Sanders MJ, Illingworth CJR, et al. Single-cell RNA-seq reveals hidden transcriptional variation in malaria parasites. Elife. (2018) 7:e33105. doi: 10.7554/eLife.33105

Conflict of Interest: The authors declare that the research was conducted in the absence of any commercial or financial relationships that could be construed as a potential conflict of interest.

Copyright (C) 2019 Kimenyi, Wamae and Ochola-Oyier. This is an open-access article distributed under the terms of the Creative Commons Attribution License (CC BY). The use, distribution or reproduction in other forums is permitted, provided the original author(s) and the copyright owner(s) are credited and that the original publication in this journal is cited, in accordance with accepted academic practice. No use, distribution or reproduction is permitted which does not comply with these terms. 